\title{
Evaluation of Air Pollution Tolerance Index (APTI) as a tool to monitor pollution and green belt development: A review
}

\author{
Bhavika Sharma ${ }^{1}$, Sandeep Sharma ${ }^{1}$, S. K. Bhardwaj ${ }^{2}$, Lakhvinder Kaur $^{3}$ and \\ Abhay Sharma ${ }^{2}$ \\ ${ }^{1}$ Silviculture and Tree Improvement Division, Himalayan Forest Research Institute, Panthaghati, Shimla (H.P.), \\ INDIA \\ ${ }^{2}$ Department of Environmental Sciences, Dr. Y.S. Parmar University of Horticulture and Forestry, Nauni, Solan \\ (H.P.), INDIA \\ ${ }^{3}$ Department of Environment Studies, Panjab University, Chandigarh, INDIA \\ *Corresponding author. E-mail: ahaanasharma@gmail.com
}

Received: November 18, 2016; Revised received: March 16, 2017; Accepted: August 8, 2017

ABSTRACT: Air pollution is a global phenomenon arising out of the unsustainable, unplanned and rapid development. The quality of air is deteriorating day by day because of rising concentrations of various gases in the atmosphere. Presently, no such system has been developed ever that completely eliminates air pollutants, but nature has created many systems to deal with the harmful results of different anthropogenic activities up to a certain limit. Some plants can survive well with higher pollutant concentrations and act as pollution scavenger. Green plants act as a sink and filter to minimize air pollution by absorption, adsorption, detoxification, accumulation and/or metabolization without sustaining serious decline in growth, thus improving air quality by providing oxygen to the atmosphere. The plants which can withstand higher pollutant concentrations can serve as tolerant species and may be suggested to act as pollution scavengers. In the present study the air pollution tolerance index of some plants has been reviewed which are widely distributed throughout India and may prove helpful for the abatement of elevated air pollution levels such as Mangifera indica, Azardirachta indica, Saraca indica, Ficus religiosa, Ficus benghalensis, Shorea robusta and Bougainvillea spp. The wild indigenous species are superior performers in air pollution reduction as compared to the cultivated non indigenous species. The screening out of tolerant plant species from the sensitive ones can provide a database which may help landscapers to design green belts around industries and National Highways.

Keywords: Air pollution tolerance index, Anthropogenic activities, Gaseous exchange, Green belts, Physiological adaptation

\section{INTRODUCTION}

India is a developing country and as the economy is growing, air pollution levels are also increasing. Rising air pollution is one of the major problems emerging due to rapid industrialization. The degradation of air quality is a major environmental problem that affects many urban and industrial sites and the surrounding regions worldwide (Kuddus et al., 2011).

Environment Protection Agency (EPA) has established national ambient air quality standards (NAAQS) for six of the most common air pollutants carbon monoxide, lead, ground-level ozone $\left(\mathrm{O}_{3}\right)$, particulate matter (PM), nitrogen dioxide $\left(\mathrm{NO}_{2}\right)$, and sulphur dioxide $\left(\mathrm{SO}_{2}\right)$. These are known as "criteria" air pollutants and their presence in ambient air is generally due to numerous diverse and widespread sources of emissions. Most of the Indian cities are facing extremely high level of urban air pollution particularly in the form of $\mathrm{CO}, \mathrm{SO}_{2}$, $\mathrm{NO}_{2}, \mathrm{PM}$ and Respirable Suspended Particulate Matter (RSPM). Transport sectors contributes a major share to environmental pollution (around 70\%) such as $\mathrm{CO}$, which is one of the major pollutants contributing $90 \%$ of total emission followed by hydrocarbons (Shrivastava et al., 2013).

About $80 \%$ of cities violate the air pollution regulation standards in India (CPCB 2014). Emissions are increasing day by day due to expansion of urbanization, industrialization, power and agricultural activities. CPCB in 2009 found 43 out of 88 industrial areas were critically polluted in India. Dust from roads, cement industry, construction activities, soils, coal burning are the key sources of suspended particulate matter. In India coal based thermal power plants are the major contributor of $\mathrm{SO}_{2}$ emissions and oxides of nitrogen are emitted from many sources like thermal power plants, fossil fuel combustion in automobiles and burning of wood; while $\mathrm{CO}$ is released by incomplete combustion of fossil fuels and wood.

India is a developing country and as the economy is growing, air pollution levels are also increasing. Rising air pollution is one of the major problems emerging 
due to rapid industrialization. The degradation of air quality is a major environmental problem that affects many urban and industrial sites and the surrounding regions worldwide (Kuddus et al., 2011). The APTI based on four parameters including leaf total chlorophyll, ascorbic acid leaf extract $\mathrm{pH}$, and relative water content (RWC) is used for identifying tolerance levels of plant species (Beg et al.,1990; Chauhan, 2010; Singh and Rao, 1991). Air pollutants affect plant growth adversely (Rao, 2006; Bhatia, 2006; Sodhi, 2007; Horsfall and Spiff (1998). Landscapers use the APTI to select tolerant plant species (Liu and Ding, 2008). APTI has also been used to rank plant species in their order of tolerance to air pollution (Raza and Murthy, 1988; Singh and Rao, 1983). With the help of extensive studies on APTI of different plants, the response of plant species towards air pollution can be determined. Currently, many plant species are known to have effective APTI values, but this review study provides information about the commonly growing plant species such as Mangifera indica, Azardirachta indica, Saraca indica, Ficus religiosa, Ficus benghalensis, Shorea robusta, and Bougainvillea spp., as these species are widely distributed throughout India and have been studied with respect to their APTI values. Air pollution tolerance index is an efficient tool to screen out the pollution tolerant plant species which can be used for development of green belts.

APTI as an air pollution monitoring tool: Tolerance level of plants can be evaluated by calculating an index known as air pollution tolerance index (APTI) based on four biochemical and physiological parameters viz. chlorophyll, ascorbic acid, $\mathrm{pH}$, relative water content (Singh and Rao, 1983, Dwivedi et al., 2007). APTI is an empirical relation which evaluates the tolerance level of plant species towards air pollution by considering leaf biochemical parameters such as total chlorophyll, ascorbic acid, leaf extract $\mathrm{pH}$, and relative water content (RWC). APTI has been used in studies like green belt development (Shannigrahi et al., 2004), traffic noise reduction (Pathak et al., 2011) and pollution mitigation along roadsides and around industries. Different plants respond differently to air pollution and it has been observed that plants growing in the apparently polluted environment have higher APTI than the ones growing in a lesser polluted environment (Agbaire and Esiefarienrhe, 2009). Plants have the ability to absorb the atmospheric dust and can also dilute gaseous pollutants concentration in atmosphere by changing them to harmless metabolites after absorption of pollutants. They absorb gaseous pollutants through the leaf pores and remove them. Twigs, leaves and stems attenuate particulate matter and wash them to the ground by precipitation. $\mathrm{CO}$ and NO are less soluble gases and plants do not uptake them; while $\mathrm{SO}_{2}$ dissolves in the cells to give bisulphite and sulphite ions. Sulphite is toxic and at low concentrations it is metabolized by chloroplasts to sulphate, which is non toxic and at sufficiently low concentrations, bisulphite and sulphite are effectively detoxified by plants and $\mathrm{SO}_{2}$ air pollution then provides a sulphur source for the plant (Zeiger, 2006). At lower concentrations, $\mathrm{NO}_{2}$ stimulates plant growth and causes reduction in plant growth at higher concentration by inhibiting photosynthesis.

APTI is a method suggested by Singh and Rao (1983) to screen out the tolerant species from the sensitive ones. This index takes into account all the important biochemical and physiological parameters of plants. It is calculated according to the following formula:

$$
\mathrm{APTI}=\frac{\mathrm{AA}(\mathrm{TCH}+\mathrm{pH})+\mathrm{RWC}}{10}
$$

Where, $\mathrm{AA}=$ Ascorbic Acid content $(\mathrm{mg} / \mathrm{g}) ; \mathrm{pH}=$ Leaf extract $\mathrm{pH} ; \mathrm{TCH}=$ Total chlorophyll content $(\mathrm{mg} / \mathrm{g}) ; \mathrm{RWC}=$ Relative Water Content $(\%)$

The plant species having APTI values falling in the range of 30-100 are regarded as tolerant, those of 1729 as intemediately tolerant. The APTI of sensitive plant species ranges from 1-16 and the plant species having APTI values less than 1 are considered as highly sensitive (Table 1).

The four parameters of APTI (ascorbic acid content, total chlorophyll content, leaf extract $\mathrm{pH}$, and $\mathrm{RWC}$ ) play a significant role in determining the tolerance of plants to air pollutants (Bakiyaraj and Ayyappan, 2014; Gharge and Menon, 2012; Liu and Ding, 2008). The air pollutants settled on plants may cause injury to tolerant plants to a lesser extent whereas in sensitive plants injury might be higher. Sensitive plants can be used as early warning indicators of air pollution.

Ascorbic acid is an antioxidant found in the growing parts of plants and influences the resistance to adverse environmental conditions, including air pollution (Keller and Schwager, 1977). Its activity is $\mathrm{pH}$ controlled and thus the ascorbic acid content is generally greater at higher $\mathrm{pH}$ and smaller at lower $\mathrm{pH}$, therefore, higher levels of leaf-extract $\mathrm{pH}$ mean more tolerance of air pollution (Singh and Verma, 2007). Ascorbic acid, a natural antioxidant in plants has been shown to play an important role in pollution tolerance (Joshi and Swami, 2007). Since it is a strong reductant, it protects chloroplast against $\mathrm{SO}_{2}$ induced $\mathrm{H}_{2} \mathrm{O}_{2}, \mathrm{O}_{2}{ }^{-}$and $\mathrm{OH}^{-}$accumulation and also protects the enzymes of the $\mathrm{CO}_{2}$ fixation cycle and chlorophyll from inactivation (Tanaka et al., 1982). Chaudhary and Rao (1977) and Varshney and Varshney (1982) are of the opinion that higher ascorbic acid of plants is a sign of their tolerance against sulphur dioxide pollution and other pollutants which are normally affecting the roadside vegetation.

Relative Water Content (RWC) of a leaf is the water present in it relative to its full turgidity and is associated with protoplasmic permeability in cells which caus- 
Table 1. Response of plants towards air pollution.

\begin{tabular}{lll}
\hline S.N. & $\begin{array}{l}\text { APTI value or } \\
\text { range }\end{array}$ & $\begin{array}{l}\text { Response/Degree or Level } \\
\text { of Tolerance }\end{array}$ \\
\hline 1. & $30-100$ & Tolerant \\
2. & $17-29$ & Immediately tolerant \\
3. & $1-16$ & Sensitive \\
4. & $<1$ & Highly sensitive \\
\hline
\end{tabular}

es loss of water and dissolved nutrients, resulting in early senescence of leaves (Agarwal and Tiwari, 1997).

Total Chlorophyll Content (TCH) of plants signifies its photosynthetic activity as well as the growth and development of biomass. It varies from species to species with the age of leaf along with the pollution level and other biotic and abiotic conditions (Katiyar and Dubey, 2000). Chlorophyll pigments exist in highly organized state and may undergo several photochemical reactions under any stress induced such as oxidation, reduction, pheophytinisation and reversible bleaching. Hence any alteration in chlorophyll concentration may change the morphological, physiological and biochemical behaviour of the plant.

Air pollution monitoring by plants: Air pollutants affect the physiology of the plants which results in abnormal growth. Plants respond variably to different pollutants individually and in combination (Emberson et al., 2001).Sensitive plants behave as early warning system and can be used to assess the extent of pollution in the milieu (Nouchi, 2002).

Air pollution can be defined as the fluctuation in any atmospheric constituent from the value that would have existed without human intervention and is considered as one of the most serious problems the world is facing today. The ever increasing human population has led to serious damages to the environment. It is more complex than other existing environmental challenges of the world, since the air pollutants are more easily dispersed than other type of pollutants and no physical or chemical method is available to ameliorate the aerial pollutants at a large scale. The only methods to control the pollutants include by making technological improvements like designing more efficient automobiles and instruments which contribute to air pollution to a lesser extent. The other alternatives to mitigate air pollution include the interventions such as biological methods. Plants are the primary receptors of a large number of air pollutants. They provide an enormous leaf area for impingement, absorption and accu- mulation of air pollutants to reduce the level of air pollution.

The major air pollutants include oxides of nitrogen (NOx), oxides of sulphur (SOx), oxides of carbon (CO, $\mathrm{CO}_{2}$ ), hydrocarbons and PM. The main sources leading to these air pollutants include industries, burning of fossil fuels and transportation. The air pollutants emitted out of motor vehicles are one of the major culprits for stress induced changes in plants. Air pollution may directly affect the plants via leaves or indirectly via soil acidification. So the study of APTI of plant species is important so that they can be recommended for the plantation near high traffic roads and near pollution causing industries.

There may be changes in canopy area, plant height, plant biomass, chlorophyll content, ascorbic acid, relative water content, nitrogen content etc. in plants growing at sites which receive higher pollution. They show visible or subtle changes depending upon their sensitivity level. It has been reported that when exposed to the air pollutants, most plants experience physiological changes before exhibiting visible changes in the leaves. Leaves are generally used as an experimental material since they take up large amount of pollutants. The response of plants towards air pollution is assessed by the APTI developed by Singh and Rao during the Symposium of Air Pollution Control held in 1983 at IIT, Delhi.

Significance of APTI in green belt development: Studies conducted by various researchers suggest that APTI is an efficient tool for green belt development. In a study conducted by Kour and Raina, 2014; while observing the APTI values of various plant species, Ficus religiosa was found to be comparatively more tolerant and displayed the highest APTI value (4.76 \pm 0.16 ) where as Pterospernum acerifolium was found to be more sensitive to air pollution with minimum APTI value $(1.65 \pm 0.19)$. The order of tolerance observed for the species studied was Ficus religiosa $>$ Polyalthia longifolia $>$ Thevetia peruviana $>$ Pterospernum acerifolium. The chlorophyll content (Chlorophyll A, Chlorophyll B and Total chlorophyll content) was found to be less in plant species growing at the polluted site as compared to the species growing at the control site. Reduction in $\mathrm{pH}$ and ascorbic acid content values was observed in all the plant species growing at the polluted site. Reduction in values of RWC in the plants.

Various studies have indicated that plants are affected

Table 2. APTI values of various plant species.

\begin{tabular}{llllllll}
\hline References & $\begin{array}{l}\text { Azardirachta } \\
\text { indica }\end{array}$ & $\begin{array}{l}\text { Ficus } \\
\text { religiosa }\end{array}$ & $\begin{array}{l}\text { Polyalthia } \\
\text { longifolia }\end{array}$ & $\begin{array}{l}\text { Eucalyptus } \\
\text { spp. }\end{array}$ & $\begin{array}{l}\text { Tectona } \\
\text { grandis }\end{array}$ & $\begin{array}{l}\text { Ficus bengha- } \\
\text { lensis }\end{array}$ & $\begin{array}{l}\text { Mangifera } \\
\text { indica }\end{array}$ \\
\hline $\begin{array}{l}\text { Prajapati } \\
\text { et al., 2008 }\end{array}$ & 19.01 & 21.62 & - & - & 13.45 & 19.15 & 19.65 \\
$\begin{array}{l}\text { Pandey } \\
\text { et al., 2015 }\end{array}$ & 15.08 & 23.35 & 22.88 & - & 13.29 & 26.01 & 16.89 \\
$\begin{array}{l}\text { Lakshmi } \\
\text { et al., 2009 }\end{array}$ & 13.55 & 25.77 & 15.10 & 11.34 & - & 11.70 & 11.82 \\
\hline
\end{tabular}


by increased atmospheric pollution (Gaikwad et al., 2004). In experiments conducted for the study of air pollution induced changes in the photosynthetic pigments of plant species, a reduction in Chlorophyll A, B and carotenoid has been noticed in the leaf samples collected from the polluted areas as compared to the ones collected from control areas and thus, it has been concluded that vehicular air pollution causes a reduction in the concentration of photosynthetic pigments in the trees which are exposed to roadside pollution (Joshi and Swami, 2007). In a study conducted by Joshi and Swami (2007), higher APTI values were recorded for Shorea robusta (9.02) and lowest for Mangifera indica (6.76) at a polluted site of Haridwar. In a study along the Coimbatore-Ooty Highway in Tamil Nadu, it was found that among the 27 species, Azadirachta indica (among trees), Ricinus communis, Bougainvillea spectabilis and Calotropis gigantea (among shrubs), Datura stramonium and Amaranthus viridis (among herbs) and Cucurbita pepo (among climbers) showed a high degree of APTI (Karthiyayini et al., 2005).

The APTI values of various plant species were studied by Bora and Joshi (2014) such as Saraca indica (13.71), Azadirachta indica (12.98), Shorea robusta (12.64), Eucalyptus spp. (12.61), Ficus religiosa (12.61) and Tectona grandis (13.33), which suggested that all the given plant species justifies the APTI and hence prove themselves as pollution reducers and should be recommended for roadside plantation.

The foliar surface configuration and biochemical changes were observed in Ficus religiosa and Thevetia nerifolia and it was also observed that auto exhaust pollution showed marked alterations in photosynthetic pigments, protein and cysteine contents and also in the leaf area and foliar surface architecture of plants growing at a highly polluted site as compared to a low polluted site (Verma and Singh, 2006). Madan and Verma (2015) estimated the values of APTI of three plant species namely, Ficus religiosa, Azadirachta indica and Polyalthia longifolia and it was observed that values of all the biochemical parameters were found to be pollution load dependent. Maximum APTI value was observed in case of Azadirachta indica and minimum value was observed for Ficus religiosa. The level of tolerance of air pollution by automobile exhaust for tree species including Mango (Mangifera indica), Sagon (Tectona grandis), Sal (Shorea robusta) and Eucalyptus spp. around Haridwar was studied to determine the APTI of these tree species and it was found that the highest value of APTI was recorded for Sal (11.27) and lowest value of APTI was recorded for Eucalyptus (7.19). The study revealed that Shorea robusta was the most suitable species to work as pollution sink (Swami and Chauhan, 2015). In a study conducted on 23 plant species near a steel factory by Liu and Ding (2008), it was observed that through the growing season, some species exhibited APTI variation related to changes in air temperature and water status of plants, thus laying stress on the need to measure APTI throughout the growing season.

Begum and Harikrishna (2010) studied tolerance of plant species with respect to APTI values and heavy metal concentration (cadmium, zinc and lead). It was observed that Ficus religiosa, Azadirachta indica and Pongamia pinnata were the most tolerant species in the industrial area where the research was conducted. It has also been observed that chlorophyll in lichens is very sensitive to changes in environmental stress including air pollution. Jyothi and Jaya (2010) conducted research on the periodic evaluation of APTI of three plant species along roadsides in Thiruvananthapuram in Kerala and found that Polyalthia longifolia expressed highest APTI values and was thus a tolerant variety. Kuddus et al. (2011) found that out of the seven economically important plants that were studied, Mangifera indica was relatively tolerant (18.51) while Artocarpus spp. was found to be most sensitive of all the species studied (8.75). It was observed that the correlated values of air pollutants alter foliar biochemical features of plants. It was suggested that Azadirachta indica which was the most tolerant species may be used as a sink. It was also observed that all the biochemical parameters showed variations upon exposure to air pollution (Thawale et al., 2011).

Joshi and Bora (2011) calculated APTI values of eight plant species and found that Ficus religiosa had the highest APTI value (20.94) among all the plant species studied and Eucalyptus spp. had the lowest value (13.41). The study indicated that ambient air pollution had a negative impact on the physiological characteristics of plants. Panigrahi et al. (2012) found that out of the 16 plant species studied, most of the species were sensitive to air pollution and few species were intermediately tolerant such as Mangifera indica (17.81), $\mathrm{Fi}$ cus religiosa (22.44), Anacardium occidentalis (17.39) and Zizipus spp. (24.76). Pant and Tripathi (2012) observed that many parameters such as chlorophyll, protein, soluble sugar, free amino acid, ascorbic acid, nitrate reductase, superoxide dismutase and peroxidise in the leaves were pollution dependent.

While studying the impacts of air pollution in plants around a cement industry in Coimbatore, Radhapriya et al. (2012) observed that significant variation in individual parameters and APTI was noticed in all the plant species studied and all the plants surrounding the cement industry were indicative of high pollution exposure as compared to the results obtained from plants at the control site. Out of the 27 plant species studied, $37 \%$ of the plants were tolerant to air pollution, $5 \%$ were immediately tolerant and 33\% were highly susceptible to air pollution. The tolerant species were Mangifera indica, Psidium guajava and Bougainvillea spp. Thambavni and Maheshwari (2012) studied APTI 
values of fifteen tree species and found that Mangifera indica and Ficus religiosa were the most tolerant species and suggested plantation of these tree species along roadsides and in areas with heavy traffic flow. Bhattacharya et al. (2013) studied the seasonal variation in APTI values in Baroda city and observed that APTI values showed insignificant seasonal variation in all the plant species except Acacia arabica. It was observed that the highest APTI value, irrespective of the season, was found to be in the following order: Polyalthia longifolia $>$ Azadirachta indica $>$ Ficus benghalensis > Acacia Arabica >Peltophorum pterocarpum $>$ Mangifera indica.

Randhi and Reddy (2013) studied APTI values of sixteen plant species and found that only Delonix regia was found to be tolerant, while Clerodendrum paniculatum, Samania saman and Azadirachta indica were found to be immediately tolerant and the remaining tree species were sensitive to air pollution.

Krishnaveni et al. (2012) selected 30 herbal trees and 30 herbal plant species for the evaluation of APTI and found that Embilica officinalis (95.81), Callistomon citrinus (86.96) and Pithecellobium dulce (84.30) showed highest APTI values in herbal tree species and Withania somnifera (88.30), Chrysanthemum coronariums (82.27), Mirabilis jalapa (74.54) showed highest APTI values among the plant species. Ficus benghalensis (26.89) and Tectona grandis (31.19) showed lowest APTI values among trees and among herbal plant species Vetiria zizaniobes (28.23) and Punica granatum (28.41) showed lowest APTI values.

Narwaria and Kushwah (2012) also observed that air pollution has direct impacts on the biochemical parameters of plants. Out of the five plant species studied, the highest APTI value at the study site was found to be of Grevillea robusta (10.06) while lowest APTI value was that of Mangifera indica (7.51). Singare and Talpade (2013) examined APTI of four plant species growing along roadsides and compared the results with plants growing at a control site. The order of tolerance was found to be Polyalthia longifolia $>$ Caesalpinia pulcherrima $>$ Tamarindus indica $>$ Delonix regia. The APTI values of all the plant species growing along the roadsides were found to be higher than the APTI values of plants growing at control sites. Suganthiet al. (2013) observed that the values of APTI and secondary metabolites like ascorbic acid, phenolic and flavonoids content exhibited a significant positive correlation with pollution load. Species like Azadirachta indica, Pongamia pinnata and Polyalthia longifolia were suggested to be used as bio-indicators of air pollution and thus, can be used in air pollution management practices. The APTI of plant species (Azardirachta indica (21), Ficus benghalensis (19.10), Ficus religiosa (19.73), and Mangifera indica (12.36) was also studied by Dwivedi and Tripathi (2007)in surrounding areas of coal fired industries.

Yannawar and Bhosle (2014) calculated the APTI values of plants growing along roadsides in Nanded city and found that Azadirachta indica, Moringa oleifera, Euginia jambolana and Tamarindus indica were found to be tolerant while Mangifera indica, Polyalthia longifolia, Ficus benghalensis, Delonix regia, Acacia nilotica, Leucaena leucocephala and Dalbergia sissoo were found to be immediately tolerant and Ficus religiosa, Phyllanthus emblica, Ficus glomerata and Eucalyptus spp. were found to be sensitive. Panigrahi et al. (2012) in a study found that Mangifera indica was the most tolerant species with an APTI value of 20.80 followed by Bougainvillea spectabilis $(20.32)>$ Nerium indicum (18.94) > Azadirachta indica (18.73) > Calatropis procera (18.10). Joshi and Bora (2014) studied APTI values of six plant species and the order of tolerance of plants towards air pollution noticed was: Saraca indica (13.71) > Azadirachta indica (12.98) > Shorea robusta $(12.64)>$ Eucalyptus spp. and Ficus religiosa (12.61) > Tectona grandis (12.43). The tolerant plants selected from such studies could play diverse roles in the structure and function of vegetation that may be used for restoration in the future. The air pollution tolerance index of plants varies seasonally from species to species along with the stages of their life cycle. Sensitive species have been reported to be ideal bioindicators and the tree species with high APTI values are tolerant to and can be used as sinks. Intrinsic nature of the each plant species plays a major role in determining the air pollution tolerance level of a species. Chlorophyll content, ascorbic acid, $\mathrm{pH}$ and relative water content of each and every plant varies from one another. The commonly occurring plant species like Mangifera indica, Azardirachta indica, Saraca indica, Ficus religiosa, Ficus benghalensis, Shorea robusta, and Bougainvillea spp. have good air pollution tolerance index. The wild indigenous species are superior performers in air pollution reduction as they grow naturally in their native habitats as compared to the cultivated non indigenous species. The main objective of this paper was to evaluate and screen the various aspects like plant species, seasonal variations, life cycle and their availability in the area to categorize plants according to their air pollution tolerance index values for the development of effective green belt zone for the abatement of elevated pollution levels.

\section{Conclusion}

The air pollution tolerance index is a good basis to select plants for development of green belts to mitigate air pollution. The tolerant plant species can help in mitigating and reducing adverse health impacts from persistent exposure to air pollutants along with regulating ecosystem services thereby improving the local urban ecology. 


\section{ACKNOWLEDGEMENTS}

The authors are thankful to the Department of Science and Technology (DST), New Delhi for funding the study.

\section{REFERENCES}

Agarwal, S.K. and Tiwari, S.L. (1997). Susceptibility level of few plants on the basis of air pollution tolerance index. Indian Forester, 123: 319-322

Agbaire, P.O. (2009). Air pollution tolerance indices (APTI) of some plants around Erhoike-Kokori oil exploration site of Delta State, Nigeria. International Journal of Physical Sciences, 4(6): 366-368

Bakiyaraj, R. and Ayyappan, D. (2014). Air Pollution Tolerance Index of some terrestrial plants around an industrial area. International Journal of Modern Research and Reviews, 2(1): 1-7

Beg, M.U., Farooq, M., Bhargava, S. K., Kidwai, M.M. and Lal, M.M. (1990). Performance of trees around a thermal power station. Environment and Ecology, 8(3): 791 $-797$

Begum, A. and Harikrishna, S. (2010). Evaluation of some tree species to absorb air pollutants in three industrial locations of South Bengaluru, India. Journal of Chemistry, 7(S1): S151-S156

Bhatia, S.C. (2006). Environmental Chemistry. CBS Publishers and Distributors

Bhattacharya, T., Kriplani, L. and Chakraborty, S. (2013). Seasonal variation in air pollution tolerance index of various plant species of Baroda city. Universal Journal of Environmental Research and Technology, 3(2): 199201

Bora, M. and Joshi, N. (2014). A study on variation in biochemical aspects of different tree species with tolerance and performance index. The Bioscan, 9(1): 59-63

Chaudhary, C.S. and Rao, D.N. (1977). Study of some factors in plants controlling their susceptibility to $\mathrm{SO}_{2}$ pollution. Proceedings of Indian National Science Academy, 43: 236-241

Chauhan, A. (2010). Photosynthetic pigment changes in some selected trees induced by automobile exhaust in Dehradun, Uttarakhand. New York Science Journal, 3 (2): 45-51

CPCB (2014). National ambient air quality status 2012, Central Pollution Control Board, New Delhi

CPCB (2009). Comprehensive environmental assessment of industrial clusters. New Delhi: Central Pollution Control Board, New Delhi

Dwivedi, A.K. and Tripathi, B.D. (2007). Pollution tolerance and distribution pattern of plants in surrounding area of coal-fired industries. Journal of Environmental Biology, 28(2): 257-263

Emberson, L. D., Ashmore, M. R., Murray, F., Kuylenstierna, J. C. I., Percy, K. E., Izuta, T., and Agrawal, M. (2001). Impacts of air pollutants on vegetation in developing countries. Water, Air, and Soil Pollution, 130(14): $107-118$

Gaikwad, U.S., Ranade, C.D. and Gadgil, J.M. (2006). Plants as bio-indicators of automobile exhaust pollution - a Case study of Sangli City. Journal of the Institution of Engineers (India), Part EN, Environmental Engineering Division, 86: 26-28
Gharge, S. and Menon, G.S. (2012). Air Pollution Tolerance Index (APTI) of certain herbs from the site around Ambernath MIDC. Asian Journal of Experimental Biological Sciences, 3(3): 543-547

Horsfall, M. and Spiff, A.I. (1998). Principles of Environmental pollution with physical chemical and biological emphasis. Port Harcourt, Metropolis Limited, 62-124

Joshi, N. and Bora, M. (2011). Impact of air quality on physiological attributes of certain plants. Report and Opinion, 3(2): $42-47$

Joshi, P.C. and Swami, A. (2007). Physiological responses of some trees under roadside automobile pollution stress around city of Haridwar, India. Environmentalist, 27: 365-374

Jyothi, S.J. and Jaya, D.S. (2010). Evaluation of air pollution tolerance index of selected plant species along roadsides in Thiruvananthapuram, Kerala. Journal of Environmental Biology, 31(3): 379-386

Karthiyayini, R., Ponnammal, N.R. and Joseph, R. (2005). Air pollution tolerance index of certain plants of Coimbatore-Ooty highways, near ITI area, Coimbatore, Tamilnadu. Pollution Research, 24(4): 801-803

Katiyar, V. and Dubey, P.S. (2000). Growth behaviour of two cultivars of maize in response to $\mathrm{SO}_{2}$ and $\mathrm{NO}_{2}$. Journal of Environmental Biology, 21(4): 317-323

Keller, T. and Schwager, H. (1977). Air pollution and ascorbic acid. European Journal of Forest Pathology, 7(6): 338-350

Kour, B. and Raina, A.K. (2014). Assessment of air pollution tolerance levels of some plant species of Jammu. Environment Conservation Journal, 15(1/2): 89-93

Krishnaveni, M., Usha, S. and Kowsalya, R. (2012). Evaluation of air pollution tolerance index of selected herbal tree and plant species (leaves) with in the Periyar University campus, Salem, Tamil nadu, India. Journal of Pharmacy Research, 5(6): 3219-3222

Kuddus, M., Kumari, R. and Ramteke, P.W. (2011). Studies on air pollution tolerance of selected plants in Allahabad city, India. Journal of Environmental Research and Management, 2(3): 042-046

Lakshmi, P. S., Sravanti K.L., and Srinivas N. (2009). Air pollution tolerance index of various plant species growing in industrial areas. The Ecoscan 2, 203-206

Liu, Y.J. and Ding, H. (2008). Variation in air pollution tolerance index of plants near a steel factory: Implication for landscape-plant species selection for industrial areas. WSEAS Transactions on Environment and Development, 4(1): 24-32

Madan, S. and Verma, P. (2015). Assessment of air pollution tolerance index of some trees in Haridwar City, Uttarakhand. Journal of Environmental Biology, 36(3):645-648

Narwaria, Y.S. and Kush, K. (2012). Environmental assessment of air pollution on road side plants species at Dehradun, Uttarakhand, India. Journal of Environmental Research and Development, 7(2): 710-714

Nouchi I. (2002). Plants as bioindicators of air pollution. Air Pollution and Plant Biotechnology, 11: 41-60

Pandey, A. K., Pandey, M., Mishra, A., Tiwary, S. M. and Tripathi, B. D. (2015). Air pollution tolerance index and anticipated performance index of some plant species for development of urban forest. Urban Forestry \& Urban Greening, 14(4): 866-871 
Panigrahi, T., Das, K.K., Dey, B.S., Mishra, M. and Panda, R.B. (2012). Air Pollution Tolerance Index of various plants species found in FM University Campus, Balasore, Odisha, India. Journal of Applicable Chemistry, 1 (4): $519-523$

Pant, P.P. and Tripathi, A.K. (2012). Analysis of some biochemical parameters of plants as indicator of air pollution. Journal of Environmental Science, Computer Science and Engineering and Technology, 1(1): 14-21

Pathak, V., Tripathi, B.D. and Mishra, V.K. (2011). Evaluation of anticipated performance index of some tree species for green belt development to mitigate traffic generated noise. Urban Forestry and Urban Greening, 10 (1): 61-66

Prajapati, S. K. and Tripathi B. D. (2008). Anticipated Performance Index of some tree species considered for green belt development in and around an urban area: A case study of Varanasi city, India. Journal of environmental management, 88(4):1343-1349

Radhapriya, P., Gopalakrishnan, A.N., Malini, P. and Ramachandran, A. (2012). Assessment of air pollution tolerance levels of selected plants around cement industry, Coimbatore, India. Journal of Environmental Biology, 33(3): 635.-641

Randhi, U.D. and Reddy, M.A. (2013). Air Pollution Tolerance Levels of selected urban plant species in industrial areas of Hyderabad (AP), India. Environment, 2(6): 294 $-295$

Rao, C.S. (2007). Environmental Pollution Control Engineering. New Age International

Raza, S.H., Murthy, M.S.R. and Ahmed, A. (1988). Air pollution tolerance index of certain plants of Nacharam Industrial Area, Hyderabad. Indian Journal of Bota$n y$, 11(1): 91-95

Shannigrahi, A.S., Fukushima, T. and Sharma, R.C. (2004). Anticipated air pollution tolerance of some plant species considered for green belt development in and around an industrial/urban area in India: an overview. International Journal of Environmental Studies, 61(2): 125-137

Shrivastava, R.K., Saxena, N. and Gautam, G. (2013). Air pollution due to road transportation in India: A review on assessment and reduction strategies. Journal of Environmental Research and Development, 8(1): 69-77

Singare, P.U. and Talpade, M.S. (1926). Physiological responses of some plant species as a bio-indicator of roadside automobile pollution stress using the air pollution tolerance index approach. International Journal of Plant Research, 3(2): 9-16

Singh, S.K., Rao, D.N., Agrawal, M., Pandey, J. and Naryan, D. (1991). Air pollution tolerance index of plants. Journal of Environmental Management, 32(1): 45-55

Singh, S.K. and Rao, D.N. (1983). Evaluation of plants for their tolerance to air pollution. In Proceedings of symposium on air pollution control. Indian Association for Air Pollution Control. New Delhi, 218-224

Singh, S.N. and Verma, A. (2007). Phytoremediation of Air Pollutants: A Review. In: Environmental Bioremediation Technologies, Springer, Berlin Heidelberg, 293 314

Sodhi, G.S. (2005). Fundamental concepts of environmental chemistry. Alpha Science International Limited

Suganthi, P., Ganeshkumar, R.S., Govindaraju, M., Selvaraj, M. and Kumar, P. (2013). Estimation of Biochemical Characters of plants in response to vehicular air pollution stress in Riruchirappalli city corporation, Tamil Nadu, India, International Journal of Recent Scientific Research, 4(8): 1282-1289

Swami, A. and Chauhan, D. (2015). Impact of air pollution induced by automobile exhaust pollution on air pollution tolerance index. International Journal of Scientific Research, 4(3): 342-343

Tanaka, K., Otsubo, T. and Kondo, N. (1982). Participation of Hydrogen Peroxide in the Inactivation of Calvincycle SH Enzymes in SO2-fumigated Spinach Leaves, Plant Cell Physiology, 28: 1009-1018

Thambavni, D.S. and Maheshwari J. (2012). Evaluation of Anticipated Performance Index of certain tree species in Virudhnagar, India. International Congress on Informatics, Environment, Energy and Applications-IEEA, IPCSIT Vol. 38. IACSIT Press, Singapore

Thawale, P.R., Babu, S.S., Wakode, R.R., Singh, S.K., Kumar, S. and Juwarkar, A.A. (2011). Biochemical changes in plant leaves as a biomarker of pollution due to anthropogenic activity. Environmental Monitoring and Assessment, 177(1-4): 527-535

Varshney, S.R.K and Varshney, C.K. (1985). Response of peroxidase to low levels of $\mathrm{SO}_{2}$. Environmental and Experimental Botany, 25: 107-114

Verma, A. and Singh, S.N. (2006). Biochemical and ultrastructural changes in plant foliage exposed to autopollution. Environmental Monitoring and Assessment, 120(1-3): 585-602

Yannawar, V.B. and Bhosle, A.B. (2014). Air pollution tolerance index of various plant species around Nanded city, Maharashtra, India. Journal of Applied Phytotechnology in Environmental Sanitation, 3: 23-28

Zeiger E., (2006). The Effect of Air Pollution on Plants, Plant Physiology, Fourth Edition (On line), Editors Lincoln Taiz and Eduardo Zeiger, 2006 